\title{
Molecular phylogeny of Dioscorea (Dioscoreaceae) in East and Southeast Asia
}

\author{
K.-M. Hsu ${ }^{1,2}$, J.-L. Tsai ${ }^{1}$, M.-Y. Chen ${ }^{1}$, H.-M. Ku³, S.-C. Liu ${ }^{1}$
}

Key words

atpB-rbcL

Dioscorea

matK

molecular phylogeny

$r b c L$

$\operatorname{trnL-F}$

\begin{abstract}
The phylogenetic relationships of Dioscorea, including sections Botryosicyos, Combilium, EnantiophylIum, Lasiophyton, Opsophyton, Shannicorea and Stenophora, are reconstructed with chloroplast $\operatorname{trnL}-F, \mathrm{matK}, r b c L$ and atpB-rbcL sequence data, covering a total of 72 accessions including 48 ingroup species and five outgroup species from East and Southeast Asia. The seven Asian sections do reflect the genetic relationships among the species that they include. In summary, $D$. sect. Combilium and sect. Shannicorea are recognized as closely related sections with moderate support. The results also support Burkills treatment of subsect. Euopsophyton (D. bulbifera) as sect. Opsophyton and subsect. Macrourae (D. sansibarensis) as sect. Macroura. In addition, there is a well-supported sister relationship between $D$. sect. Lasiophyton and sect. Botryosicyos. The level of morphological characters and molecular divergence within $D$. sect. Enantiophyllum is low, but the members of this group could still be distinguished from each other.
\end{abstract}

Published on 31 May 2013

\section{INTRODUCTION}

Dioscorea L. is the largest genus of Dioscoreaceae with about 600 species distributed in Southeast Asia, Africa, Central America, South America and other tropical and subtropical regions (Huber 1998). Dioscorea includes important vegetatively reproducing tuber crops, known as yams. Yams have played a significant role in the advent of agriculture in Southeast Asia including Taiwan (e.g., D. alata and $D$. esculenta) and equatorial Africa (e.g., D. cayenensis, D. dumetorum and D. rotundata) (Ayensu \& Coursey 1972, Coursey 1981). Dioscorea species are used for food and pharmaceutical products. Species such as $D$. nipponica and $D$. zingiberensis contain diosgenin, which provides one of the important raw materials for the synthesis of steroid hormone drugs (Zhai et al. 2009, Zhang et al. 2010). It has been reported that $D$. bulbifera could be effective for curing thyroid diseases and cancer (Liu et al. 2009).

Since Dioscorea is a large genus, many researchers have proposed infrageneric classifications of Dioscorea. Knuth (1924) has proposed 58 sections in Dioscorea, most of which are still used today. Prain \& Burkill $(1936,1938)$ presented several new sections for the Asian members of Dioscorea. In comparison to Kuth (1924) they placed greater emphasis on seed characters, underground organ and male inflorescence morphology. Burkill (1960) proceeded to the arrangement of the Old World sections of the genus Dioscorea, dividing 220 species into 23 sections. Recently, Huber (1998) has proposed 28 sections of Dioscorea including Borderea, Epipetrum, Rajania, Tamus and Testudinaria. However, more detailed studies of the infrageneric classification of Dioscorea have revealed that several sections seem to be artificial groupings, and many species are not fit to their section boundaries. For example, compound-leaved yams

\footnotetext{
1 Department of Life Sciences, National Chung Hsing University, Taichung, Taiwan.

2 Endemic Species Research Institute, Nantou, Taiwan.

${ }^{3}$ Department of Agronomy, National Chung Hsing University, Taichung, Taiwan; corresponding authors e-mail: hmku@email.nchu.edu.tw; scliu@dragon.nchu.edu.tw.
}

in the Old World (D. sect. Lasiophyton, sect. Trieuphorostemon and sect. Botryosicyos) have been treated as one to three sections by different systematists (Knuth 1924, Prain \& Burkill 1936, Ding \& Gilbert 2000).

Phylogenetic relationships of Dioscorea have presented a challenge to systematists for many years because of the difficulties in species identification, which is due to a continuous variability of morphological characters, especially of aerial parts, such as leaves (Pavan Kumar et al. 2007, Wilkin et al. 2005). Further, many morphological characters are shared by different species, which make the identification and classification of the genus a rather difficult task. For example, some classifications have considered $D$. batatas, $D$. doryphora and $D$. potanini as synonyms of $D$. polystachya, because those species have many morphological characters in common (Ding \& Gilbert 2000).

A further question is whether these morphological groups correctly reflect their genetic relationships within Dioscorea. Recent studies have analysed molecular datasets to provide additional indications of the relationships within this genus. The phylogenetic relationships of six species $(D$. gracillima, $D$. nipponica, $D$. quinqueloba, $D$. septemloba, $D$. tenuipes and $D$. tokoro) in $D$. sect. Stenophora were investigated based on DNA sequences of the phosphoglucose isomerase (Kawabe et al. 1997). It was reported that $D$. tenuipes and $D$. tokoro were clustered into a clade, while the rest species formed a separate clade.

Furthermore, chloroplast sequence data has been used to examine the phylogenetic relationships within Dioscorea. Wilkin \& Caddick (2000) found that the palaeotropical compound-leaved yams were classified into two monophyletic groups based on a combined analysis of chloroplast sequence data and morphological characters. Later, the phylogenetic relationships of 67 Dioscorea taxa were reconstructed based on chloroplast $r b c L$ and matK sequence data (Wilkin et al. 2005). They found that the main Old World groups (such as the left-twining $D$. sect. Stenophora and the right-twining $D$. sect. Enantiophyllum) were monophyletic. However, these studies included a limited sampling of Asian species and the obtained phylogenetic resolution 
Table 1 List of sample sources and Genbank accession numbers of the sequences used in this study.

\begin{tabular}{|c|c|c|c|c|c|c|}
\hline \multirow[t]{2}{*}{ Taxon } & \multirow[t]{2}{*}{ Location } & \multirow[t]{2}{*}{ Voucher } & \multicolumn{4}{|c|}{ GenBank accession numbers } \\
\hline & & & $\operatorname{trn} L-F$ & matK & $r b c L$ & atpB-rbcL \\
\hline Dioscorea alata L. 1 & Nantou, Taiwan & Chen 56 (TCB) & JQ733816 & JQ733662 & JQ733739 & JQ733585 \\
\hline D. alata L. 2 & Phitsanulok, Thailand & Y.S. Liang D. 29 (TCB) & JQ733843 & JQ733689 & JQ733766 & JQ733612 \\
\hline D. alata L. 3 & Bali, Indonesia & Hsu 242 (TCB) & JQ733870 & JQ733716 & JQ733793 & JQ733639 \\
\hline D. batatas Decne. & Taipei, Taiwan & Hsu 201 (TCB) & JQ733824 & JQ733670 & JQ733747 & JQ733593 \\
\hline D. benthamii Prain \& Burkill 1 & Hong Kong, China & Venus 101 (TCB) & JQ733820 & JQ733666 & JQ733743 & JQ733589 \\
\hline D. benthamii Prain \& Burkill 2 & Hong Kong, China & Venus 102 (TCB) & JQ733849 & JQ733695 & JQ733772 & JQ733618 \\
\hline D. benthamii Prain \& Burkill 3 & Hong Kong, China & Venus 103 (TCB) & JQ733850 & JQ733696 & JQ733773 & JQ733619 \\
\hline D. bulbifera L. 1 & Zhanghua, Taiwan & Hsu 99 (TCB) & JQ733821 & JQ733667 & JQ733744 & JQ733590 \\
\hline D. bulbifera L. 2 & Dhaka, Bangladesh & Lu 16195 (TCB) & JQ733830 & JQ733676 & JQ733753 & JQ733599 \\
\hline D. bulbifera L. 3 & Guizhou, China & Y.S. Liang 1034 (TCB) & JQ733834 & JQ733680 & JQ733757 & JQ733603 \\
\hline D. bulbifera L. 4 & Phitsanulok, Thailand & Y.S. Liang 2147 (TCB) & JQ733841 & JQ733687 & JQ733764 & JQ733610 \\
\hline D. bulbifera L. 5 & Guizhou, China & Ann 3836 (TNM) & JQ733867 & JQ733713 & JQ733790 & JQ733636 \\
\hline D. bulbifera L. 6 & Bali, Indonesia & Hsu 241 (TCB) & JQ733869 & JQ733715 & JQ733792 & JQ733638 \\
\hline D. cirrhosa Lour. & Yunlin, Taiwan & Chen 51 (TCB) & JQ733817 & JQ733663 & JQ733740 & JQ733586 \\
\hline D. cirrhosa var. cylindrica C.T.Ting \& M.C.Chang 1 & Guangdong, China & Y.S. Liang 2656 (TCB) & JQ733883 & JQ733729 & JQ733806 & JQ733652 \\
\hline D. cirrhosa var. cylindrica C.T.Ting \& M.C.Chang 2 & Guangdong, China & Y.S. Liang 2691 (TCB) & JQ733884 & JQ733730 & JQ733807 & JQ733653 \\
\hline D. collettii Hook.f. 1 & Nantou, Taiwan & Hsu 101 (TCB) & JQ733818 & JQ733664 & JQ733741 & JQ733587 \\
\hline D. collettii Hook.f. 2 & Lanyu, Taiwan & Hsu 76 (TCB) & JQ733882 & JQ733728 & JQ733805 & JQ733651 \\
\hline D. collettii var. hypoglauca (Palib.) C.Pei \& C.T.Ting & Hunan, China & Zhang 90619057 (TAIF) & JQ733874 & JQ733720 & JQ733797 & JQ733643 \\
\hline D. cumingii Prain \& Burkill & Lanyu, Taiwan & Chen 18 (TCB) & JQ733822 & JQ733668 & JQ733745 & JQ733591 \\
\hline D. doryphora Hance 1 & Zhanghua, Taiwan & Hsu 56 (TCB) & JQ733823 & JQ733669 & JQ733746 & JQ733592 \\
\hline D. doryphora Hance 2 & Lanyu, Taiwan & Chen 22 (TCB) & JQ733847 & JQ733693 & JQ733770 & JQ733616 \\
\hline D. esculenta (Lour.) Burkill & Luzon, Philippines & Lu 20826 (TCB) & JQ733878 & JQ733724 & JQ733801 & JQ733647 \\
\hline $\begin{array}{l}\text { D. esculenta var. spinosa (Roxb. ex } \\
\text { Prain \& Burkill) R.Knuth }\end{array}$ & Jiayi, Taiwan & Chen 20 (TCB) & JQ733833 & JQ733679 & JQ733756 & JQ733602 \\
\hline D. exalata C.T.Ting \& M.C.Chang 1 & Guizhou, China & Y.S. Liang 1037 (TCB) & JQ733835 & JQ733681 & JQ733758 & JQ733604 \\
\hline D. exalata C.T.Ting \& M.C.Chang 2 & Guangdong, China & Lu 21091 (TCB) & JQ733879 & JQ733725 & JQ733802 & JQ733648 \\
\hline D. fordii Prain \& Burkill & Yunnan, China & Shui 3526 (TNM) & JQ733860 & JQ733706 & JQ733783 & JQ733629 \\
\hline D. formosana Knuth & Taoyuan, Taiwan & Chen 42 (TCB) & JQ733845 & JQ733691 & JQ733768 & JQ733614 \\
\hline D. futschauensis Uline ex R.Knuth & Mazu, Taiwan & Hsu 32 (TCB) & JQ733825 & JQ733671 & JQ733748 & JQ733594 \\
\hline D. gracillima Miq. & Jiangxi, China & Tan 95288 (TNM) & JQ733863 & JQ733709 & JQ733786 & JQ733632 \\
\hline D. hamiltonii Hook.f. & Taipei, Taiwan & Hsu 202 (TCB) & JQ733832 & JQ733678 & JQ733755 & JQ733601 \\
\hline D. hemsleyi Prain \& Burkill 1 & Yunnan, China & Yang 18467 (TNM) & JQ733855 & JQ733701 & JQ733778 & JQ733624 \\
\hline D. hemsleyi Prain \& Burkill 2 & Yunnan, China & Zhu 7106 (TAIF) & JQ733875 & JQ733721 & JQ733798 & JQ733644 \\
\hline D. hispida Dennst. 1 & Nantou, Taiwan & Hsu 211 (TCB) & JQ733826 & JQ733672 & JQ733749 & JQ733595 \\
\hline D. hispida Dennst. 2 & Bali, Indonesia & Hsu 244 (TCB) & JQ733872 & JQ733718 & JQ733795 & JQ733641 \\
\hline D. japonica Thunb. 1 & Pingdong, Taiwan & Hsu 94 (TCB) & JQ733819 & JQ733665 & JQ733742 & JQ733588 \\
\hline D. japonica Thunb. 2 & Guizhou, China & Y.S. Liang 1046 (TCB) & JQ733837 & JQ733683 & JQ733760 & JQ733606 \\
\hline D. japonica Thunb. 3 & Kyoto, Japan & Hsu 231 (TCB) & JQ733844 & JQ733690 & JQ733767 & JQ733613 \\
\hline D. kamoonensis Kunth 1 & Guizhou, China & CHC 7539 (TCB) & JQ733838 & JQ733684 & JQ733761 & JQ733607 \\
\hline D. kamoonensis Kunth 2 & Hunan, China & Ma 1145 (TNM) & JQ733866 & JQ733712 & JQ733789 & JQ733635 \\
\hline D. lepcharum Prain \& Burkill & Dhaka, Bangladesh & Lu 16156 (TCB) & JQ733829 & JQ733675 & JQ733752 & JQ733598 \\
\hline D. martini Prain \& Burkill & Yunnan, China & Yang 14136 (TNM) & JQ733864 & JQ733710 & JQ733787 & JQ733633 \\
\hline D. melanophyma Prain \& Burkill 1 & Guizhou, China & CHC 9203 (TCB) & JQ733842 & JQ733688 & JQ733765 & JQ733611 \\
\hline D. melanophyma Prain \& Burkill 2 & Yunnan, China & Yang 14137 (TNM) & JQ733865 & JQ733711 & JQ733788 & JQ733634 \\
\hline D. nipponica Makino & Hunan, China & Tan 71 (TAIF) & JQ733851 & JQ733697 & JQ733774 & JQ733620 \\
\hline D. nitens Prain \& Burkill & Guangdong, China & Y.S. Liang 2628 (TCB) & JQ733887 & JQ733733 & JQ733810 & JQ733656 \\
\hline D. nummularia Roxb. & Luzon, Philippines & Lu 20549 (TCB) & JQ733877 & JQ733723 & JQ733800 & JQ733646 \\
\hline D. pentaphylla L. 1 & Dhaka, Bangladesh & Lu 16206 (TCB) & JQ733831 & JQ733677 & JQ733754 & JQ733600 \\
\hline D. pentaphylla L. 2 & Yunnan, China & Yang 20890 (TNM) & JQ733858 & JQ733704 & JQ733781 & JQ733627 \\
\hline D. polystachya Turcz. 1 & Mazu, Taiwan & Hsu 31 (TCB) & JQ733827 & JQ733673 & JQ733750 & JQ733596 \\
\hline D. polystachya Turcz. 2 & Tianjin, China & Ching 189 (TNM) & JQ733853 & JQ733699 & JQ733776 & JQ733622 \\
\hline D. potanini Prain \& Burkill & Hunan, China & Huang 644 (TNM) & JQ733856 & JQ733702 & JQ733779 & JQ733625 \\
\hline D. quinqueloba Thunb & Kyushu, Japan & Yonekura 6186 (TNM) & JQ733859 & JQ733705 & JQ733782 & JQ733628 \\
\hline D. sansibarensis Pax 1 & Yunnan, China & Hsu 221 (TCB) & JQ733839 & JQ733685 & JQ733762 & JQ733608 \\
\hline D. sansibarensis $\mathrm{Pax} 2$ & Iringa, Tanzania & G. Massawe 285 (TNM) & JQ733852 & JQ733698 & JQ733775 & JQ733621 \\
\hline D. scortechinii var. parviflora Prain \& Burkill & Hanoi, Vietnam & Lu 19238 (TCB) & JQ733868 & JQ733714 & JQ733791 & JQ733637 \\
\hline D. sp. A & Phitsanulok, Thailand & Y.S. Liang D. 26 (TCB) & JQ733840 & JQ733686 & JQ733763 & JQ733609 \\
\hline D. sp. B & Guizhou, China & Y.S. Liang 1050 (TCB) & JQ733846 & JQ733692 & JQ733769 & JQ733615 \\
\hline D. sp. C & Jiangxi, China & Tan 97894 (TNM) & JQ733854 & JQ733700 & JQ733777 & JQ733623 \\
\hline D. sp. D & Phitsanulok, Thailand & Y.S. Liang 3539 (TCB) & JQ733880 & JQ733726 & JQ733803 & JQ733649 \\
\hline D. sp. E & Hong Kong, China & Y.S. Liang D. 178 (TCB) & JQ733881 & JQ733727 & JQ733804 & JQ733650 \\
\hline D. sp. F & Guangdong, China & Y.S. Liang 2594 (TCB) & JQ733885 & JQ733731 & JQ733808 & JQ733654 \\
\hline D. sp. G & Luzon, Philippines & Lu 20548 (TCB) & JQ733876 & JQ733722 & JQ733799 & JQ733645 \\
\hline D. sp. $\mathrm{H}$ & Bali, Indonesia & Hsu 243 (TCB) & JQ733871 & JQ733717 & JQ733794 & JQ733640 \\
\hline D. subcalva Prain \& Burkill 1 & Guizhou, China & Y.S. Liang 1045 (TCB) & JQ733836 & JQ733682 & JQ733759 & JQ733605 \\
\hline D. subcalva Prain \& Burkill 2 & Guizhou, China & Wang 1-0588 (TAIF) & JQ733873 & JQ733719 & JQ733796 & JQ733642 \\
\hline D. subcalva var. submollis C.T.Ting \& P.P.Ling 1 & Yunnan, China & Y.S. Liang D. 39 (TCB) & JQ733848 & JQ733694 & JQ733771 & JQ733617 \\
\hline D. subcalva var. submollis C.T.Ting \& P.P.Ling 2 & Yunnan, China & Chen 6177 (TNM) & JQ733861 & JQ733707 & JQ733784 & JQ733630 \\
\hline D. tokoro Makino & Honshu, Japan & C.H. Chen 5805 (TNM) & JQ733862 & JQ733708 & JQ733785 & JQ733631 \\
\hline D. velutipes Prain \& Burkill & Guangdong, China & Y.S. Liang 2609 (TCB) & JQ733886 & JQ733732 & JQ733809 & JQ733655 \\
\hline D. wallichii Hook.f. & Dhaka, Bangladesh & Lu 16155 (TCB) & JQ733828 & JQ733674 & JQ733751 & JQ733597 \\
\hline D. yunnanensis Prain \& Burkill & Yunnan, China & Ma 7140 (TNM) & JQ733857 & JQ733703 & JQ733780 & JQ733626 \\
\hline Stemona tuberosa Lour. & Nantou, Taiwan & Hsu 401 (TCB) & JQ733892 & JQ733738 & JQ733815 & JQ733661 \\
\hline Stenomeris borneensis Oliv. & Luzon, Philippines & Lu 20601 (TCB) & JQ733888 & JQ733734 & JQ733811 & JQ733657 \\
\hline Tacca chantrieri André & Cultivated & Hsu 302 (TCB) & JQ733890 & JQ733736 & JQ733813 & JQ733659 \\
\hline Tacca leontopetaloides (L.) Kuntze & Pingdong, Taiwan & Hsu 301 (TCB) & JQ733889 & JQ733735 & JQ733812 & JQ733658 \\
\hline Tacca plantaginea (Hance) Drenth & Cultivated & Hsu 303 (TCB) & JQ733891 & JQ733737 & JQ733814 & JQ733660 \\
\hline
\end{tabular}


was relatively low. Therefore the phylogenetic relationships among the species of Asian Dioscorea have not been well established (e.g., in D. sect. Shannicorea). Further studies to resolve both the limits of their species and the phylogenetic relationships between them are necessary.

A complete plastid genome of a Dioscorea species is available (Hansen et al. 2007) and this provides a rich source of phylogenetic tools to unravel the genetic relationships within Dioscorea. Based on chloroplast genes including $t r n L-F$, matK, $r b c L$ and $a t p B-r b c L$ sequence data, the objectives of this study are to further clarify infrageneric classification of Asian Dioscorea and provide information for the genetic conservation of wild and cultivated yams. We examine currently recognized species within seven sections (sect. Botryosicyos, Combilium, Enantiophyllum, Lasiophyton, Opsophyton, Shannicorea and Stenophora) from East and Southeast Asia and investigate the relationships amongst these sections. We compare our results to recent studies of Dioscorea and the molecular phylogeny of Dioscorea in East and Southeast Asian is discussed.

\section{MATERIALS AND METHODS}

\section{Taxon sampling}

Our analysis of chloroplast trnL-F, matK, $r b c L$ and atpB-rbcL covered a total of 72 accessions of 48 ingroup species and five outgroup species (Table 1). These five outgroup taxa were part of Tacca and Stenomeris in Dioscoreaceae and Stemona in Stemonaceae (Caddick et al. 2002).

\section{DNA extraction, amplification and sequencing}

DNA was extracted from fresh leaves, dried leaves, or herbarium sheets using a Puregene DNA Purification kit (Gentra Systems, Minneapolis, MN, USA). Four gene products were amplified by primers trnL-5 (5'-CGAAATCGGTAGACGCTACG-3') and IGS-3 (5'-ATTTGAACTGGTGACACGAG-3') for trnL-F, matK-F (5'- ACCCCATCCCATCCATCTGGAAAT-3') and matK-R (5'-TATCCAAATACCAAATGCGTCCTG-3') for matK, rbcL-F (5'-GTTGGATTCAAAGCTGGTGTTAAAGAT-3') and rbcL-R (5'-CGTCCCTCATTACGAGCTTG-3') for $r b c L$, and atpB-2 (5'-AGCGTTGTAAATATTAGGCATCTT-3') and rbcL-2 (5'-ATCTTTAACACCAGCTTTGAATCCAAC-3') for atpB-rbcL, respectively. A total volume of $50 \mu \mathrm{IPCR}$ reaction contained $1 \mu$ l of template DNA (50-100 ng extracted genomic DNA), $1 \mu \mathrm{l}$ of $10 \mathrm{mM}$ of each primer, $2.5 \mu \mathrm{l}$ of PCR buffer, $1 \mu \mathrm{l}$ of $10 \mathrm{mM}$ dNTPs, $2.5 \mu$ l of $25 \mathrm{mM} \mathrm{MgCl}_{2}$ and $1 \mathrm{U}$ of Taq polymerase. PCR reactions were performed in a PCR thermocycler (GeneAmp 9700 PCR system; Applied Biosystems, Foster City, CA, USA) and carried out in the following conditions: an initial denaturation step at $94^{\circ} \mathrm{C}$ for $5 \mathrm{~min}$, followed by 35 cycles of $94^{\circ} \mathrm{C}$ for $1 \mathrm{~min}$, $52{ }^{\circ} \mathrm{C}$ for $1 \mathrm{~min}$ and $72{ }^{\circ} \mathrm{C}$ for 2 mins, with a final extension of $72{ }^{\circ} \mathrm{C}$ for $7 \mathrm{~min}$. The PCR amplified products were checked on a $1 \%$ agarose gel electrophoresis stained with ethidium bromide. Using Micro-Elute DNA Clean/Extraction Kit (GeneMark, Taiwan), the PCR products were purified and dissolved in $10 \mu \mathrm{l}$ $d d H_{2} \mathrm{O}$. The purified $\mathrm{PCR}$ products were sequenced with the
PCR primer pairs in both directions by an ABI Model 3100 DNA sequencer (Applied Biosystems, USA) with BigDye terminator cycle sequencing reagent (Applied Biosystems, USA).

\section{Sequence analyses}

The sequences were aligned and edited using BioEdit 7.0.1 (Hall 1999). The alignments of the concatenated sequence datasets were obtained by using CLUSTAL-X version 1.83 (Thompson et al. 1997) with manual adjustments for accuracy. Statistical analyses of the alignments were performed using MEGA v. 4 (Tamura et al. 2007).

\section{Phylogenetic analyses}

After alignment, phylogenetic analyses were conducted with PAUP* 4.0b10 (Swofford 2002) using the methods of distance and maximum parsimony (MP). Bayesian inference (BI) analyses were conducted with MrBayes 3.1.2 (Ronquist \& Huelsenbeck 2003). The optimal model of nucleotide substitution was evaluated by a likelihood ratio test with MODELTEST 3.7 (Posada \& Crandall 1998). The K81uf + I+G model with proportion of invariable sites $(\mathrm{I})=0.3661$ and gamma distribution shape parameter $(G)=0.9624$ was selected as the best model for the concatenated DNA sequence of $t r n L-F$, matK, $r b c L$ and atpB-rbcL genes.

Based on this model, a distance tree was constructed with the neighbor-joining (NJ) algorithm. In the MP analysis, characters were equally weighted and a heuristic search option with tree bisection reconnection (TBR) branch-swapping and 10 random stepwise additions was used (gaps were treated as missing data). All bootstrap values were based on 1000 replicates performed for NJ and MP. The BI analysis was run for $2 \times 106$ generations, with a sample frequency of 100 . The first 2000 trees were discarded and 18000 trees were applied in the final consensus tree. The posterior probabilities (calculated with MrBayes) were recorded to represent the support for nodes.

\section{RESULTS}

\section{Sequence characteristics and variations}

For all Dioscorea and the outgroup species, the sequenced trnL- $F$ region was $640-745 \mathrm{bp}$, the matK region $895-901 \mathrm{bp}$, the $r b c L$ region $1159 \mathrm{bp}$ and the atpB-rbcL region 690-838 bp. The lengths of the alignments are given in Table 2. The pairwise distances ( $p$-distances) among the seven Dioscorea sections ranged from 0.007 to 0.042 for combined datasets including chloroplast genome trnL-F, matK, rbcL and atpB-rbcL DNA sequences. The average $p$-distance in all the sampled Dioscorea species was 0.017 for $\operatorname{trnL}-F, 0.020$ for matK, 0.012 for $r b c L$ and 0.015 for atpB-rbcL. The $p$-distance within each section ranged from 0.000 to 0.006 for $t r n L-F, 0.000$ to 0.007 for matK, 0.000 to 0.006 for $r b c L$ and 0.000 to 0.006 for atpB-rbcL. The most divergent section was $D$. sect. Opsophyton (including the $D$. bulbifera group and $D$. sansibarensis group), in which the $p$-distance was 0.006 for the combined dataset (data not shown).

Table 2 Tree statistics and sequence information of the $t r n L-F$, matK, $r b c L$, atpB-rbcL and combined datasets.

\begin{tabular}{|c|c|c|c|c|c|}
\hline & $\operatorname{trn} L-F$ & matK & $r b c L$ & $a t p B-r b c L$ & Combined dataset \\
\hline Aligned sequence length (bp) & 896 & 907 & 1160 & 938 & 3901 \\
\hline $\mathrm{G}+\mathrm{C}$ content $(\%)$ & 33.9 & 31.8 & 44.7 & 29.8 & 34.1 \\
\hline No. parsimony informative sites & 253 & 160 & 94 & 139 & 646 \\
\hline Tree length (MP) & 651 & 390 & 323 & 374 & 1601 \\
\hline Consistency index $(\mathrm{Cl})$ & 0.69 & 0.80 & 0.52 & 0.85 & 0.78 \\
\hline Retention index (RI) & 0.83 & 0.92 & 0.80 & 0.92 & 0.90 \\
\hline
\end{tabular}




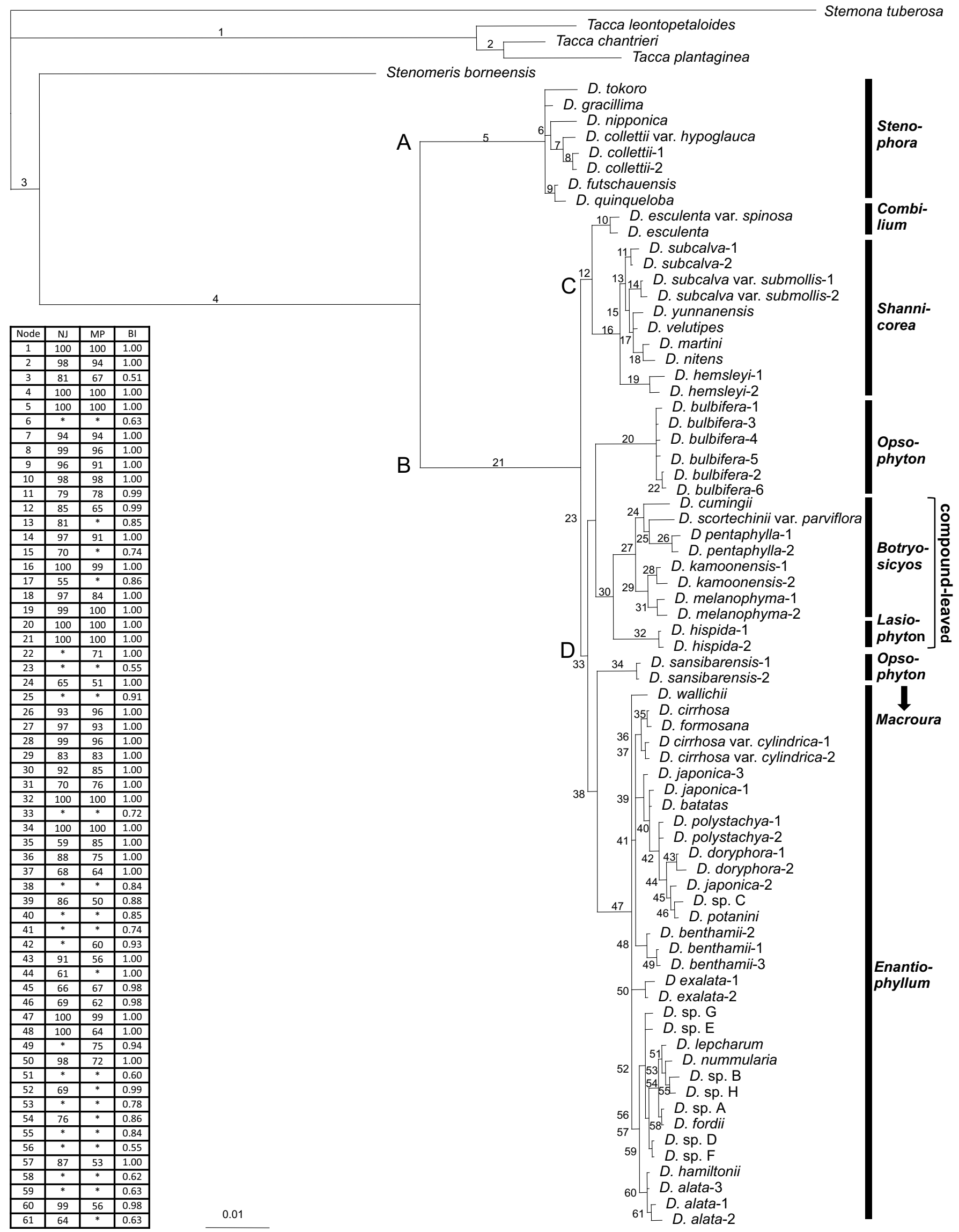

Fig. 1 Bayesian tree of Dioscorea specimens reconstructed with combined chloroplast genome $\operatorname{trnL}-F$, matK, rbcL and atpB-rbcL DNA sequences. Statistical supports for each node (node numbers on the branches of the tree) in NJ, MP and BI analyses is shown in the table on the left. An asterisk ( ${ }^{*}$ ) indicates a node value $<50 \%$. 


\section{Phylogenetic analyses}

The MP analysis of the combined dataset resulted in a single tree of 1601 steps with $\mathrm{Cl}=0.78$ and $\mathrm{RI}=0.90$. The phylogenetic tree based on the cpDNA combined datasets as reconstructed by the Bayesian method with statistical supports for each node in $\mathrm{NJ}, \mathrm{MP}$ and $\mathrm{BI}$ analyses is shown in Fig. 1. There were no supported contradictions between the topologies of NJ, MP and Bayesian consensus tree. The Dioscorea species formed a monophyletic group with maximum support at node 4 . Within Dioscorea, there were two strongly supported clades, clade $A$ (node 5, 100/100/1.00) and clade B (node 21, 100/100/1.00). Clade $B$ was further divided into two clades (C and D). Clade $C$ included two strongly supported sections, D. sect. Combilium (node 10,98/98/1.00) and $D$. sect. Shannicorea (node $16,100 / 99 / 1.00$ ), which were moderately supported (node $12,85 / 65 / 0.99$ ) as sister to each other. Clade $D$ includes five strongly supported sections. Within $D$. sect. Opsophyton, 6 individuals of $D$. bulbifera and two individuals of $D$. sansibarensis were not clustered together, but formed monophyletic clades with strong support (node 20 and 34, 100/100/1.00) individually. Next, the $D$. sect. Botryosicyos clade was strongly supported as monophyletic group (node 27, 97/93/1.00), and its sister $D$. sect. Lasiophyton was also strongly supported as monophyletic group (node 32, 100/100/1.00). Finally, D. sect. Enantiophyllum was also strongly supported as monophyletic (node 47 , 100/99/1.00).

\section{DISCUSSION}

\section{Systematic implications of the molecular phylogeny}

Based on their twining stems, compound leaves, underground organ morphology, hairs, male flowers, capsule and seed characters, the species of Asian Dioscorea can be divided into nine sections (sect. Botryosicyos, Combilium, Enantiophyllum, Lasiophyton, Opsophyton, Paramecocarpa, Shannicorea, Stenocorea and Stenophora). A total of seven out of nine sections (except $D$. sect. Stenocorea and Paramecocarpa) were included in our analysis and the phylogenetic tree of Dioscorea was reconstructed by cpDNA combined datasets. Our results show general support for the infrageneric classification of Dioscorea.

\section{The Stenophora clade}

As shown in Fig. 1, all Dioscorea species formed a monophyletic group with two distinct, strongly supported clades (clade $A$ and $B$ ). This confirms that $D$. sect. Stenophora (clade A) is sister to the rest of Dioscorea (clade B) in the systematics of the genus as reported in Wilkin et al. (2005). Many ancestral characteristics of the genus are also present in $D$. sect. Stenophora including rhizome, diploid chromosome number and single pollen aperture (Pei et al.1979, Chin et al.1985, Schols et al. 2003). Because its fossil record is the earliest of the genus Dioscorea, sect. Stenophora has been proposed as the oldest section in Dioscorea (Burkill 1960).

Furthermore, $D$. collettii was reported as a Sino-Himalayan species in Thapyai et al. (2005). Burkill (1960) had distinguished an additional species from $D$. collettii, which he called $D$. hypoglauca. However, in the most recent treatment of this species, Ding \& Gilbert (2000) defined D. hypoglauca as a variety of $D$. collettii, $D$. collettii var. hypoglauca. These two taxa exhibit continuous morphological variations and show sympatric distribution in China. Gao et al. (2008) suggested that $D$. collettii var. collettii and $D$. collettii var. hypoglauca were sister to each other with only weak support. In this study, these two taxa were also sister to each other, but with strong support (Fig. 1 node 7). In addition, the specimens of $D$. collettii var. collettii sampled from Taiwan and Lanyu Island showed three stable transversions within cpDNA trnL-F and matK regions. Thus, denser sampling is required to evaluate the intraspecific classification of $D$. collettii var. collettii in the future.

\section{The Combilium and Shannicorea clades}

Dioscorea sect. Combilium and D. sect. Shannicorea show some morphological characters in common, such as producing one or several annually renewed storage tubercles, capsules which are longer than their wide and distally-winged seeds. In the arrangement of the Old World sections of the genus Dioscorea, Burkill's (1960) has divided 220 species into 23 sections. He has emphasized on the seed characters, underground organ morphology and development, and male inflorescence morphology as the defining characteristics in his report. Describing the relationships among these 23 sections, he indicated that $D$. sect. Combilium and $D$. sect. Shannicorea were closely related. This is also supported by our result in which a novel sister relationship of $D$. sect. Combilium to $D$. sect. Shannicorea was found with moderate support (Fig. 1 node 12). Furthermore, our study is the first analysis showing the internal topology of the Shannicorea with strong support (Fig. 1 node 16). Within this monophyletic clade, four taxa are endemic to southern China (D. martini, $D$. nitens, $D$. subcalva and $D$. yunnanensis), one is distributed in Northern Thailand, Myanmar and southern China ( $D$. velutipes) and one is distributed from central China to Indochina ( $D$. hemsleyi). These five species plus one variety ( $D$. subcalva var. submollis) are grouped together and sister to $D$. hemsleyi (Fig. 1 node 16). Within this clade, a major branch is found in the $\mathrm{NJ}$ and $\mathrm{BI}$ tree, but not in the MP tree (Fig. 1 node 13). Dioscorea martini and $D$. nitens were grouped together and sister to $D$. yunnanensis and $D$. velutipes, these four species were closer to $D$. subcalva var. submollis than to $D$. subcalva. Dioscorea sect. Shannicorea comprises eight species, of which a total of six species and one variety were investigated for their phylogenetic relationships in this study. With regard to the species within $D$. sect. Shannicorea not included in this study $D$. pseudonitens Prain \& Burkill was not sister to $D$. tentaculigera Prain \& Burkill in the phylogenetic tree presented by Wilkin et al. (2005). Recently, Wilkin \& Thapyai (2011) have reported that $D$. pseudonitens is conspecific with $D$. nitens. In summary, this study should be able to provide a framework for Shannicorea clade but it would need further study to evaluate the phylogenetic position of $D$. tentaculigera in the future.

\section{The Opsophyton clade}

Dioscorea bulbifera is the main species of $D$. sect. Opsophyton distributed in the wild state in both Asia and Africa. The formation of many axillary tubers (bulbils) is the distinct characteristic of $D$. bulbifera, but intraspecific classifications are still diverse. Prain \& Burkill (1936) have treated the African form with angular bulbils as a single variety, $D$. bulbifera var. anthropophagorum, and the Asian form with globular bulbils has been divided into nine varieties according to highly variable characters such as the colour, shape, and dimension of bulbils and leaves. In this study, we found six different haplotypes of the Asian form of $D$. bulbifera (data not shown). Two accessions from Bangladesh and Indonesia ( $D$. bulbifera-2 and $D$. bulbifera-6) were grouped together and sister to the rest of $D$. bulbifera in clade $D$ (Fig. 1). Interestingly, Knuth (1924) has treated $D$. sect. Opsophyton into three subsections: 1) Euopsophyton; 2) Isocanthae; 3) Macrourae. Two species of this section, D. bulbifera (Euopsophyton) and $D$. sansibarensis (Macrourae), were also surveyed in this study. It was found that $D$. bulbifera and $D$. sansibarensis were not closely related but individually formed well-supported monophyletic clades (node 20 and 34 in Fig. 1). Consequently, the subsectional classification proposed by Knuth (1924) for 
D. bulbifera (Euopsophyton) and D. sansibarensis (Macrourae) was not agreed in our results, instead our data supported Burkill's treatment of subsect. Euopsophyton (D. bulbifera) as sect. Opsophyton and subsect. Macrourae (D. sansibarensis) as sect. Macroura (Burkill 1937).

\section{The Botryosicyos and Lasiophyton clades}

These two sections show many morphological characters in common including perennial crown with annual tubers, lefttwining, usually pubescent and spiny, compound leaves and capsules that are longer than their wide. Prain \& Burkill (1936) have combined these two sections and treated the members of $D$. sect. Botryosicyos within $D$. sect. Lasiophyton. However, these two sections show clear morphological differences to each other, such as the variations in leaflet venation, male bracts, and stamen number. Thus, the obtained phylogenetic relationships seem to be well-supported by morphological characters. As shown in Fig. 1, D. sect. Botryosicyos and D. sect. Lasiophyton were both identified in the tree as well-supported clades within the compound-leaved clade (Fig. 1 node 27 and 32). The members of $D$. sect. Botryosicyos, characterized by one main vein per leaflet, were sister to those of $D$. sect. Lasiophyton, which had several veins per leaflet.

\section{The Enantiophyllum clade}

In Wilkin et al. (2005), twelve species of $D$. sect. Enantiophyllum were sampled and found to form a monophyletic clade with strong support. Our study was based on a sampling of 24 taxa of sect. Enantiophyllum and obtained a similar result with the monophyly of the section also strongly supported (Fig. 1 node 47). Dioscorea sect. Enantiophyllum is consistently defined by right-twining stems and usually opposite leaves. This section is the largest in terms of the number of species, with about 120 species, distributed mainly in tropical Asia and Africa (Prain \& Burkill 1938), but still many species are often not clearly distinguished. There are two main groups under Enantiophyllum section, an Asian-Oceanian group and an African group. Wilkin et al. (2005) reported that the African species $D$. schimperiana Hochst. ex Kunth and the Asian species were clearly separated. In addition, it was suggested by Tostain et al. (2006) that the haplotypes of African species were different from those of the Asian-Oceanian species based on data derived from SSR markers. In this study, Asian species of this section were investigated and several groups of which relationships were not clear in previous studies were clearly identified (Fig. 1). Malapa et al. (2005) proposed that $D$. alata, the most important cultivated yam in Asia, should be grouped with $D$. nummularia and $D$. transversa together representing a southeast Asian-Oceanian gene pool, rather than to $D$. persimilis (as a synonym of $D$. hamiltonii) as reported in Wilkin et al. (2007). However, our study has surveyed three typical species, $D$. alata, $D$. nummularia and $D$. hamiltonii, and the result showed that $D$. alata and $D$. hamiltonii were grouped together with strong support (Fig. 1 node 60 ) and sister to the rest of Asian-Oceanian species.

Many species identification and nomenclatural problems of the group, from $D$. japonica to $D$. potanini, have been mentioned in previous studies. For example, Ding \& Gilbert (2000) considered that $D$. batatas, $D$. doryphora and $D$. potanini should be regarded as a synonym of $D$. polystachya. In this study, it was shown that they could be distinguished from each other (Fig. 1 nodes 40, 42, 44). However, further experiments with population-based sampling would be necessary to verify clearly the phylogenetic relationships among $D$. batatas, $D$. doryphora and $D$. potanini. In addition, it is interesting to notice that three different haplotypes of $D$. japonica are found and do not form a monophyletic group within the Enantiophyllum clade (Fig. 1). Additional synonyms and varieties of $D$. japonica were also reported in Prain \& Burkill (1938). Therefore, a denser sampling is required to evaluate the intraspecific classification of $D$. japonica in the future. Finally, Fig. 1 shows that eight right-twining species $(D$. sp. $\mathrm{A}-\mathrm{H})$ fall within the Enantiophyllum clade. The results also are congruent with those of Wilkin et al. (2005), the right-twining habit has clearly only evolved once in Asia.

In summary, this study shows that the molecular phylogenetic results are generally congruent with past morphology-based infrageneric classifications of Dioscorea. The resolution of the available phylogeny within Dioscorea was improved by adding information from the cpDNA trnL-F, matK, rbcL and atpB-rbcL combined datasets in our results. The low levels of molecular divergence within some clades (as measured by the short branch lengths) indicated that radiation might be relatively recent or at a slower rate. This hypothesis warrants further evaluation with a more extensive sample and even a higher resolution.

Acknowledgements The authors thank the Taiwan Endemic Species Research Institute, especially the help of Dr. Chi-Li Tsai and Yi-Jing Chen. Thanks also to Pi-Feng Lu, Yi-Shou Liang, Dr. Chiu-Mei Wang, Dr. T.-Y. Aleck Yang and Dr. Chih-Hsiung Chen for collecting material, and to Bo Tedards, Dr. L.-C. Lai and C.-H. Chung for their helpful comments on an earlier version of this manuscript. The kind offer of some specimen materials from TAIF and TNM for molecular experiments is also deeply appreciated. We also thank two reviewers for their helpful comments and suggestions on this manuscript.

\section{REFERENCES}

Ayensu ES, Coursey DG. 1972. Guinea yams: the botany, ethnobotany, use and possible future of yams in West Africa. Economic Botany 26, 4: $301-$ 318.

Burkill IH. 1937. The development of tuber of Dioscorea sansibarensis. Blumea, Suppl. 1: 232-237.

Burkill IH. 1960. The organography and the evolution of the Dioscoreaceae, the family of the yams. Journal of the Linnean Society (Botany) 56: 319-412.

Caddick LR, Rudall PJ, Wilkin P, Hedderson TAJ, Chase MW. 2002. Phylogenetics of Dioscoreales based on combined analyses of morphological and molecular data. Botanical Journal of the Linnean Society 138: 123-144.

Chin HC, Chang MC, Ling PP, Ting CT, Dou FP. 1985. A cytotaxonomic study on Chinese Dioscorea L. - The chromosome numbers and their relation to the origin and evolution of the genus. Acta Phytotaxonomica Sinica 23, 1: 11-18.

Coursey DG. 1981. The interaction from yam and man. Journal d'Agriculture Traditionnelle et de Botanique Appliques 28, 1: 5-21.

Ding Z, Gilbert MG. 2000. Dioscoreaceae. In: Wu Z, Raven PH (eds), Flora of China, vol. 24: 276-296. Science Press, Beijing, Missouri Botanical Garden Press, St. Louis.

Gao X, Zhu YP, Wu BC, Zhao YM, Chen JQ, Hang YY. 2008. Phylogeny of Dioscorea sect. Stenophora based on chloroplast matK, rbcL and trnL-F sequences. Journal of Systematics and Evolution 46, 3: 315-321.

Hall TA. 1999. BioEdit: a user-friendly biological sequence alignment editor and analysis program for Windows 95/98/NT. Nucleic Acids Symposium Series 41: 95-98.

Hansen DR, Dastidar S, Zhengqiu CG, Penaflor C, Kuehl J, Jeffrey V, Boore L, Jansen RK. 2007. Phylogenetic and evolutionary implications of complete chloroplast genome sequences of four early-diverging angiosperms: Buxus (Buxaceae), Chloranthus (Chloranthaceae), Dioscorea (Dioscoreaceae), and Illicium (Schisandraceae). Molecular Phylogenetics and Evolution 45: $547-563$.

Huber H. 1998. Dioscoreaceae. In: Kubitzki K (ed), The families and genera of vascular plants, vol. III: 216-235. Springer Verlag, Berlin.

Kawabe A, Miyashita NT, Terauchi R. 1997. Phylogenetic relationship among the section Stenophora in the genus Dioscorea based on the analysis of nucleotide sequence variation in the phosphoglucose isomerase (Pgi) locus. Genes and Genetic Systems 72: 253-262.

Knuth R. 1924. Dioscoreaceae. In: Engler A (ed), Das Pflanzenreich, IV.43: 1-387. Engelmann, Leipzig.

Liu H, Chou GX, Wu T, Guo YL, Wang SC, Wang CH, Wang ZT. 2009. Steroidal sapogenins and glycosides from the rhizomes of Dioscorea bulbifera. Journal of Natural Products 72, 11: 1964-1968.

Malapa R, Arnau G, Noyer JL, Lebot V. 2005. Genetic diversity of the greater yam (Dioscorea alata L.) and relatedness to D. nummularia Lam. and $\mathrm{D}$. transversa $\mathrm{Br}$. as revealed with AFLP markers. Genetic Resources and Crop Evolution 52: 919-929. 
Pavan Kumar G, Subba Rao MV, Manga V. 2007. Assessment of morphological variation in Dioscorea L. using numerical analysis. Phytomorphology 57: 95-102.

Pei C, Ting CT, Chin HC, Su P, Tang SY, Chang HC. 1979. A preliminary systematic study of Dioscorea L. sect. Stenophora Uline. Acta Phytotaxonomica Sinica 17, 3: 61-72.

Posada D, Crandall KA. 1998. Modeltest: testing the model of DNA substitution. Bioinformatics 14: 817-818.

Prain D, Burkill IH. 1936. An account of the genus Dioscorea in the East, Part 1: The species which twine to the left. Annals of the Royal Botanic Gardens, Calcutta 14: 1-210. Bengal Government Press, Alipore.

Prain D, Burkill IH. 1938. An account of the genus Dioscorea in the East, Part 2: The species which twine to the right. Annals of the Royal Botanic Gardens, Calcutta 14: 211-528. Bengal Government Press, Alipore.

Ronquist F, Huelsenbeck JP. 2003. MrBayes 3: Baysian phylogenetic inference under mixed models. Bioinformatics 19: 1572-1574.

Schols P, Furness CA, Wilkin P, Smets E, Cielen V, Huysmans S. 2003. Pollen morphology of Dioscorea (Dioscoreaceae) and its relation to systematics. Botanical Journal of the Linnean Society 143: 375-390.

Swofford DL. 2002. PAUP: Phylogenetic Analysis Using Parsimony (and other methods), version 4.0 b10. Sinauer Associates, Sunderland MA.

Tamura K, Dudley J, Nei M, Kumar S. 2007. MEGA4: Molecular Evolutionary Genetics Analysis (MEGA) software version 4.0. Molecular Biology and Evolution 24: 1596-1599.

Thapyai C, Wilkin P, Chayamarit K. 2005. The Dioscorea species of Doi Chiang Dao with particular reference to Dioscorea collettii Hook.f. (Dioscoreaceae), a new record for northern Thailand. Thai Forest Bulletin (Botany) 33: 213-219.
Thompson JD, Gibson TJ, Plewniak F, Jeanmougin F, Higgins DG. 1997. The CLUSTALX window interface: flexible strategies for multiple sequence alignment aided by quality analysis tools. Nucleic Acids Research 25: 4876-4882.

Tostain S, Scarcelli N, Brottier P, Marchand JL, Pham JL, Noyer JL. 2006. Development of DNA microsatellite markers in tropical yam (Dioscorea sp.). Molecular Ecology Notes 6: 173-175.

Wilkin P, Caddick LR. 2000. Palaeotropical compound-leaved yams (Dioscorea; Dioscoreaceae): monophyly and relationships. In: Wilson KL, Morrison DA (eds), Monocots: systematics and evolution: 497-504. CSIRO, Melbourne.

Wilkin P, Schols P, Chase MW, Chayamarit K, Furness CA, Huysmans S, Rakotonasolo F, Smets E, Thapyai C. 2005. A plastid gene phylogeny of the yam genus, Dioscorea: roots, fruits and Madagascar. Systematic Botany 30: 736-749.

Wilkin P, Thapyai C. 2011. Dioscorea pseudonitens Prain \& Burkill (Dioscoreaceae) is conspecific with Dioscorea nitens Prain \& Burkill. Thai Forest Bulletin (Botany) 39: 140-147.

Wilkin P, Thapyai C, Chayamarit K. 2007. Lectotypification of Dioscorea L. (Dioscoreaceae) names from Thailand. Kew Bulletin 62: 251-258.

Zhai CX, Lu Q, Chen XM, Peng Y, Chen L, Du SH. 2009. Molecularly imprinted layer-coated silica nanoparticles toward highly selective separation of active diosgenin from Dioscorea nipponica Makino. Journal of Chromatography A 1216: 2254-2262.

Zhang XY, Hu CG, Yao JL. 2010. Tetraploidization of diploid Dioscorea results in activation of the antioxidant defense system and increased heat tolerance. Journal of Plant Physiology 167: 88-94. 